\title{
THE EXPERIENCE OF THE UNDERGROUND CONSTRUCTION FOR THE COMPLEX OF BUILDINGS ON A SOFT SOIL IN THE CENTER OF ST. PETERSBURG
}

\author{
Mangushev R., Osokin A. \\ Saint-Petersburg State Architecture and Civil Engineering University (SPbGASU), \\ Saint-Petersburg, RUSSIA
}

\begin{abstract}
Failures of the important and unique buildings and facilities occur comparatively rarely, but in case of their occurrence, result in significant social and material damage, especially if they are associated with casualties.

The experience of the science technical monitoring of the construction of underground parking in a new hotel in the central part of St. Petersburg is given in the article. The parameters of the main underground structures and problems occurred during their construction are presented. The second part of the paper is devoted to the technologies used during the construction of the second stage of the hotel on the area of the dissembled buildings suffered from serious deformation during the construction of the underground parking for the first stage of the hotel.
\end{abstract}

Keywords: failures of buildings, underground parking, settlements of foundation, excavation pit.

\section{ОПЫТ ПОДЗЕМНОГО СТРОИТЕЛЬСТВА ДЛЯ КОМПЛЕКСА ЗДАНИЙ НА СЛАБЫХ ГРУНТАХ В ЦЕНТРЕ САНКТ-ПЕТЕРБУРГА}

\author{
Р.А. Мангушев, А.И. Осокин \\ Санкт-Петербургский государственный архитектурно-строительный университет (СПбГАСУ), \\ г. Санкт-Петербург, Россия
}

\begin{abstract}
Аннотация: Разрушения ответственных и уникальных зданий и сооружений случаются сравнительно редко, но в случае такого происшествия, результат имеет существенные социальные и материальные последствия, особенно если сопряжены с людскими потерями.

В статье приводится опыт научного сопровождения строительства подземного паркинга в комплексе нового отеля в центральной части Санкт-Петербурга. Приведены параметры основных подземных частей и проблемы, с которыми пришлось столкнуться при строительстве. Вторая часть статьи посвящена технологиям, которые были использованы при строительстве второй стадии отеля на территории разобранных зданий, претерпевших серьезные деформации при строительстве подземного паркинга для первой стадии отеля.
\end{abstract}

Ключевые слова: разрушения зданий, подземный паркинг, осадка фундамента, котлован

\section{INTRODUCTION}

Fortunately, major failures of buildings and facilities occur comparatively rarely, but in case of their occurrence, result in significant social and material damage, especially if they are associated with casualties.

As a rule, the building failures related to ground beds and foundations are the most destructive, and they are caused by errors in designing, construction and operation of facilities. In many cases, such failures result from the integrated interaction of components of such causes.

From the technical point of view, the building failures are due either to soil forced out from underneath the foundation bed (loss of ground bed stability), or to large and unacceptable settlements for given type of a building and their non-uniformity (unacceptable deformation of ground bed). Generally, the destruction of the foundation material is observed not very often. As a rule, the engineering information on building failures is extremely rare, therefore, all the more 
useful to study and analyze the available data in order to accumulate experience and to prevent disasters from occurring, failure conditions or major destructions of buildings in the future.

During the last decades in Saint Petersburg, the cause pattern essentially changed regarding the destruction of adjacent buildings when new buildings are being constructed. Thus, if in 1960-1990 the building deformations were be prevalent during operation $(70 \%)$ in relation to technological causes of deformations (30\%), then since 1990 up to date, this ratio is $35 \%$ to $65 \%$.

Departure from the construction practices in new construction and sometimes even simply gross mistakes in construction of the foundation beds and foundations are the causes for major deformations (including hazardous ones) of the loadbearing structures of the buildings and facilities of surrounding development.

\section{HAZARDOUS DEFORMATIONS OF ADJACENT BUILDINGS IN CONSTRUCTION OF NEVSKY PALACE HOTEL SUBSTRUCTURE ON NEVSKY PROSPEKT, ST.PETERSBURG}

In 1992, it was started the reconstruction of the Baltiyskaya Hotel and its remodeling as modern Nevsky Palace Hotel. The high status of the hotel required that an underground car parking was constructed under the main part of the building (Figure 1).

The designing and reconstruction were carried out by foreign companies. It was not planned to underpin the foundations of the hotel facade part facing Nevsky Prospekt and the foundation on the side of

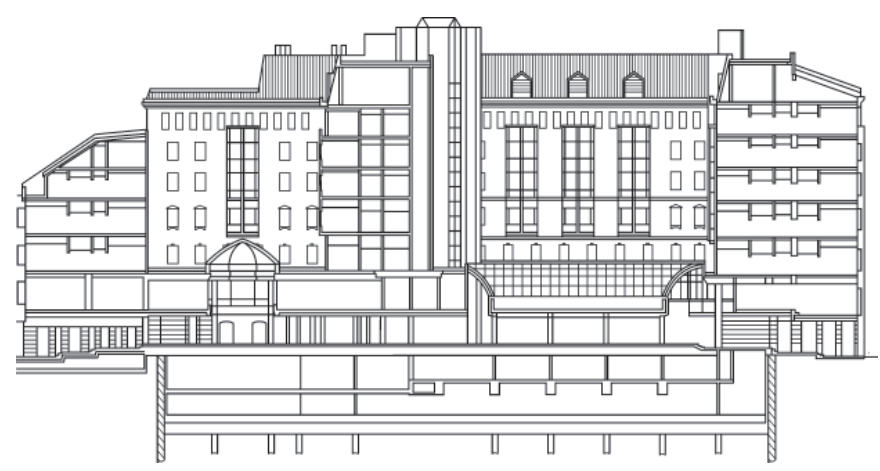

Figure 1. Diagram of underground car parking construction under Nevsky Palace Hotel the additional entrance from Stremaynnaya Street. These parts of the building are supported by the old rubble stone foundations.

On the side of Nevsky Prospekt, the foundations under the facade wall are rubble-stone ones formed by bedding limestone on sand-and-lime mortar and have the bed depth of $2,95 \mathrm{~m}$. Timber sleepers were found under their bed.

After the central part of the hotel, a 8-m deep pit was excavated and around it, a diaphragm wall was constructed that was made of secant (having an intersection) augured cast-in-situ piles $20 \mathrm{~m}$ long with a cross section of $\mathrm{D}=0,8 \mathrm{~m}$. The piles were made using the technology of drilling with casing pipe and delivering concrete through a tremie pipe from bottom upwards.

Initially, cracks started appearing in the surrounding buildings during the penetration of the first ten pipes. Apparently, it was occurring the consolidation of the bearing layers of the ground bed - fine-grained and silty sand under the foundation beds of these buildings - and the destructuration of the underlying stratified thixotropic sandy loams and loams. In the process of the construction operations, cracks continued opening and new cracks appeared. It might be associated with the destructurated water-saturated soils flowing in through the open end of the pipe and then being taken off by an auger.

The most considerable damages occurred in the nearby buildings in the process of constructing "even" piles when drilling in the concrete of the previously constructed piles. Obviously, the vibration action that takes place in drilling of the "primary" piles with special-purpose drilling tools provided with three-cone bits around the perimeter resulted in the thixotropic destructuration of soil and the deterioration of its strength and deformation properties. The soil transformed into the running state and, in the absence of so-called "soil plug", easily got through to the bottom of the borehole, which led to an additional scope of the soil excavation in drilling the boreholes and to the development of wider subsidence trough. These deformations has major effect on the further damage to the masonry strength of the nearby buildings. The settlements of 17 and 13 $\mathrm{cm}$ occurred at the nearest points of the foundations of the buildings in Nevsky Prospekt that were located nearby the excavation pit. 


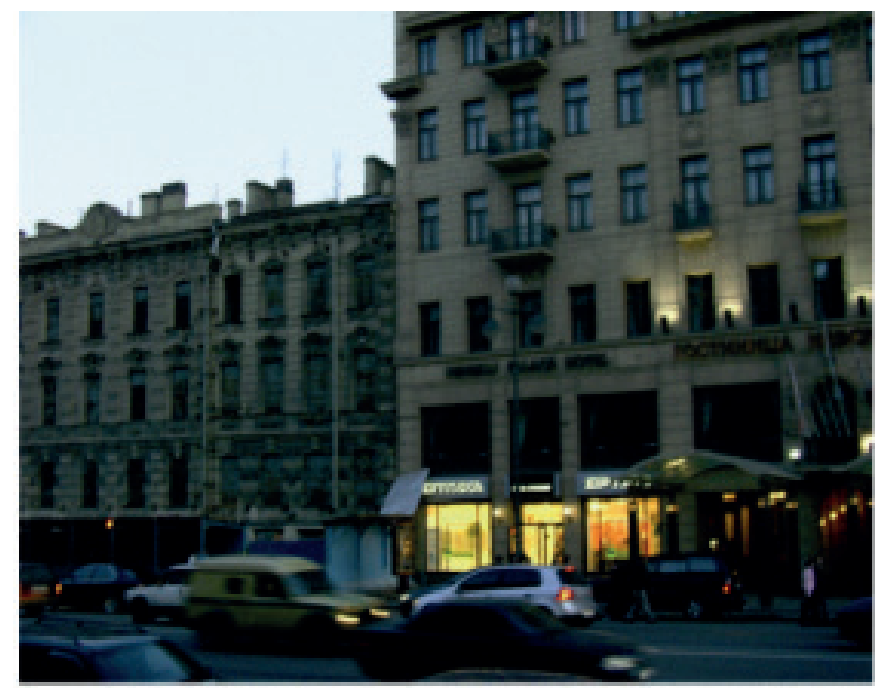

a)

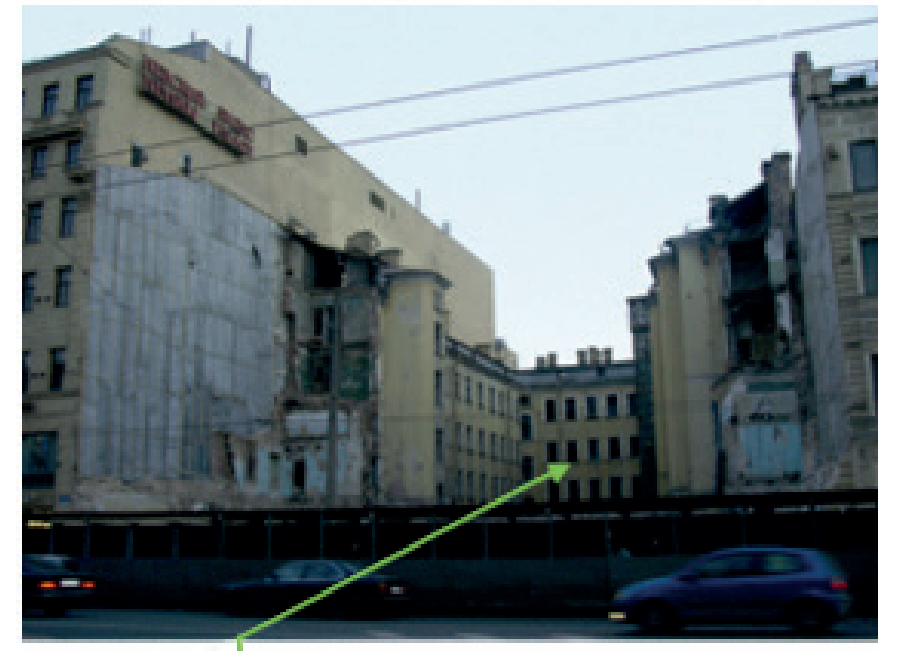

b)

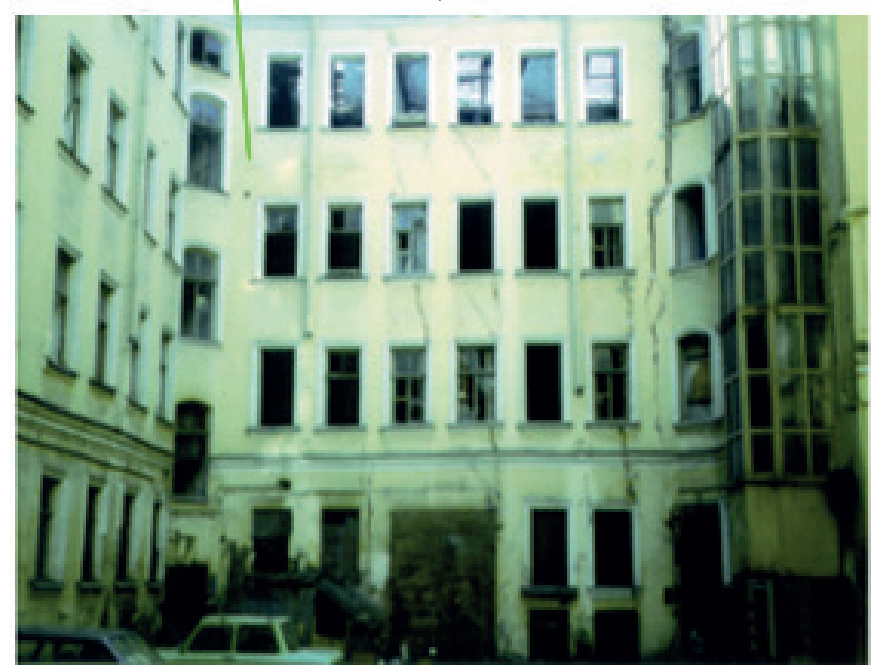

c)

Figure 2. General view of hazardousdamages of buildings in the vicinity of hotel in Nevsky Prospekt ( $a$ and $b$ ) and Stremyannaya Street (c)
The resulting deformations in the envelopes of the surrounding buildings lead to the relocation of the inhabitants of five buildings in Nevsky Prospekt and neighbor Stremyannaya Street (Fig. 2).

\section{ATTACHING OF TWO NEW BUILDINGS ON DRILLED CAST-IN-SITU PILES TO EXISTING BUILDING OF OPERATING NEVSKY PALACE HOTEL}

At the end of 2005, in the place of the demolished buildings at 55 and 59, Nevsky Prospekt, the works started to construct the foundations of new buildings for the Corinthia Nevsky Palace Hotel.

It was planned to construct Buildings No. 59 (without basement) and No. 55 with a basement 4,5 m deep on drilled cast-in-situ piles $32 \mathrm{~m}$ long and 880 and $620 \mathrm{~mm}$ in diameter using a casing pipe.

The demolished buildings were seriously damaged in 1992 when a diaphragm wall was constructed by the

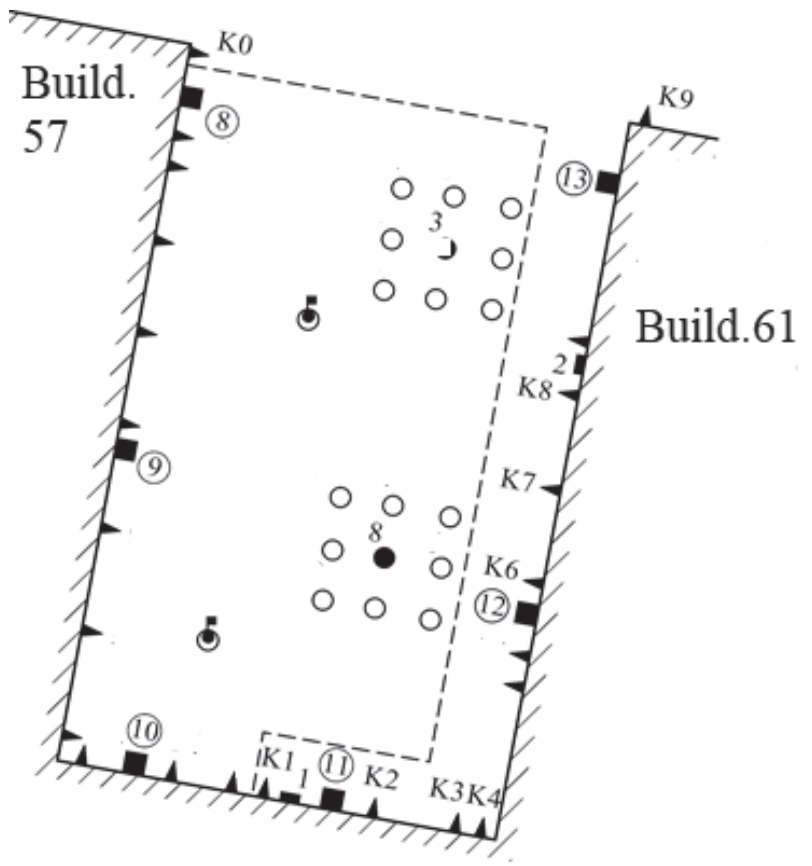

Figure 3. Layout of seismic pickups, settlement benchmarks and tell-tales;

Legend: - - seismic receiver installation points;

----- Outline of excavation pit;

- - Tell-tale and its number;

$\Delta$ - Settlement benchmarks; Monitoring well o control underground water level (measurement of piezometric level);

- - Test piles and its number; - - Anchor piles 
tangent pile method for the underground car parking. Prior to starting the works, the buildings in Nevsky Prospekt and Stremyannaya Street surrounding the two construction sites were surveyed and fitted with tell-tales installed on the existing cracks and with deformation benchmarks for geodetic monitoring. As an example, Figure 3 shows the as-built diagram of the layout of seismic pickups, settlement benchmarks and tell-tales of the monitoring wells to monitor the underground water levels, etc.

In total, observations were carried out twice a week for 95 benchmarks and more than 50 tell-tales. Four wells were used to monitor the underground water levels [1]. When carrying out the works related to underpinning of the foundations and ground beds of the buildings surrounding the construction site by the method of injecting cement grout into the contact area, as well as when constructing the foundations of the drilled cast-in-situ piles, their vibration impact on the enclosing structures of the neighboring buildings was controlled.

a)

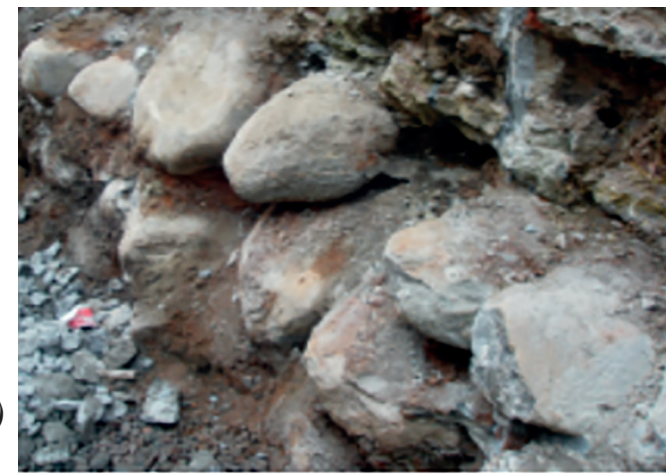

b)

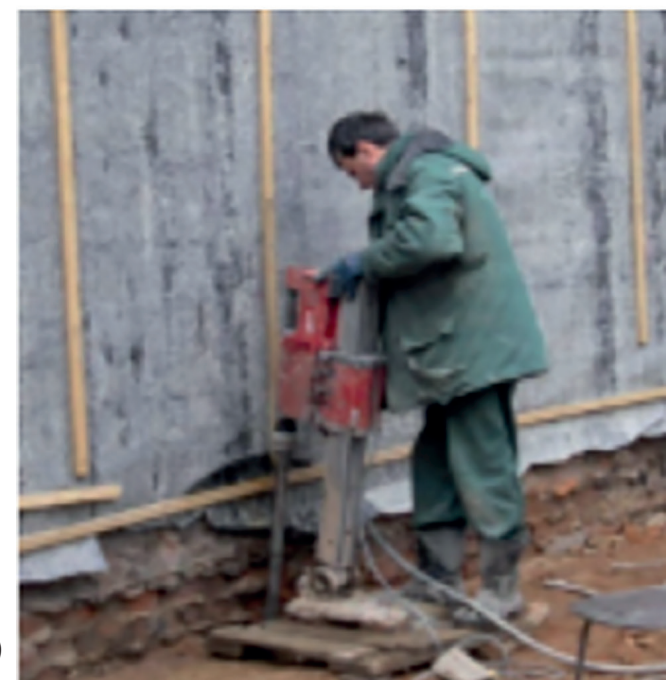

Figure 4. Underpinning of foundations and ground bed of building in Stremyannaya Street ( $a$ and $b$ )
The foundation of the neighboring building, which was erected in the beginning the XIX century, were the stone masonry, but the down part of it put granite steening. This was required use injection of the compound cement mortar to provide the continuity of foundation before piling work (Fig. 4a). Figure $4 \mathrm{~b}$ shows a process of underpinning the building foundations using the Hilty equipment.

Figure 5a shows a picture of the process of measuring vibrations of the walls of the surrounding buildings. The taken measurements of the vibration acceleration in the load-bearing structures of the buildings allowed establishing, in particular, that the process of underpinning the foundations and ground beds is safe, according to the technology applied, for the walls of the building, and that it was not acceptable to use more than one drilling rig at a time on the construction site. At the simultaneous operation of two and more self-propelled drilling rigs of the BG 25 type, the measured vibration acceleration in the building walls

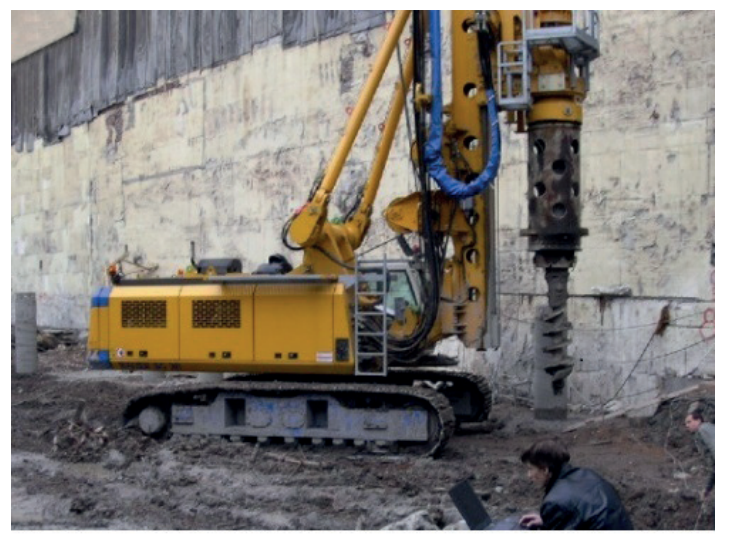

a)

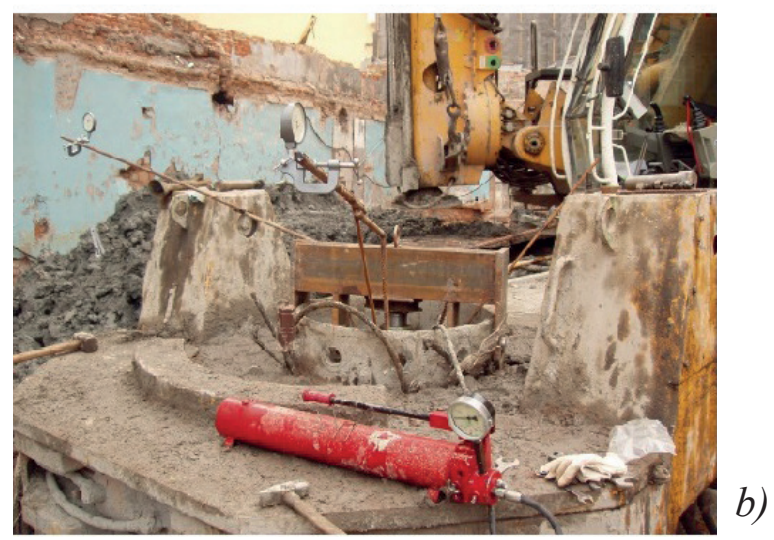

Figure 5. The complex science investigations on the construction site: taking vibration measurements during the construction of drilled cast-in-situ piles (a); the stamp test of the soil on the bottom pile's level (b). 
exceeded the maximum permissible values b) and might cause the structures to be destroyed.

Prior to starting the mass construction of the drilled cast-in-situ piles, the static tests were carried out on test piles, and the tests showed that their load-carrying capacity was at least $2000 \mathrm{kN}$, which is considerably higher than their design load (Figure 6).

Further in the mass construction of the above piles, random sampling was performed regarding the quality and integrity of the body of the drilled castin-situ piles by non-destructive testing integrity of the body of the drilled cast-in-situ piles by nondestructive testing methods using seismic-acoustic instrument IDS-1 [ 2 ]

The monitoring of the settlement benchmarks on the neighboring buildings showed that, when

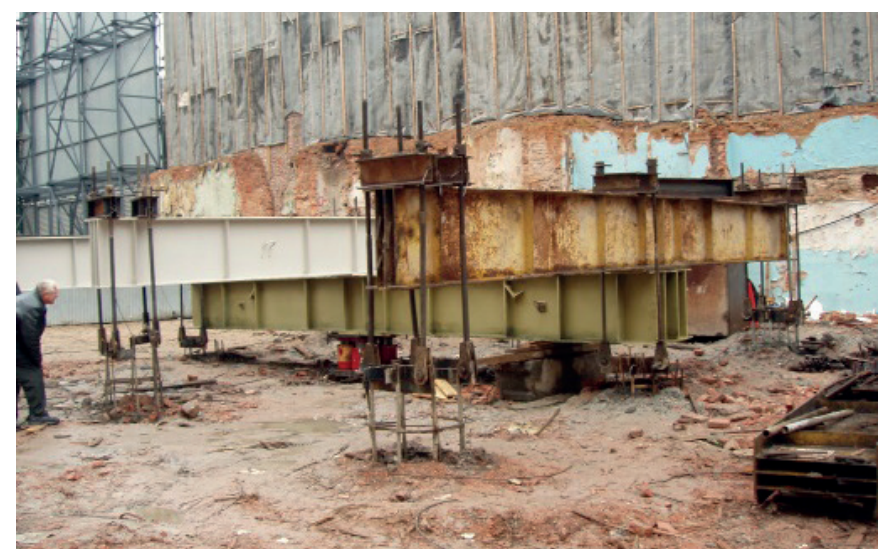

Figure 6. Static tests of piles using hydraulic jacks

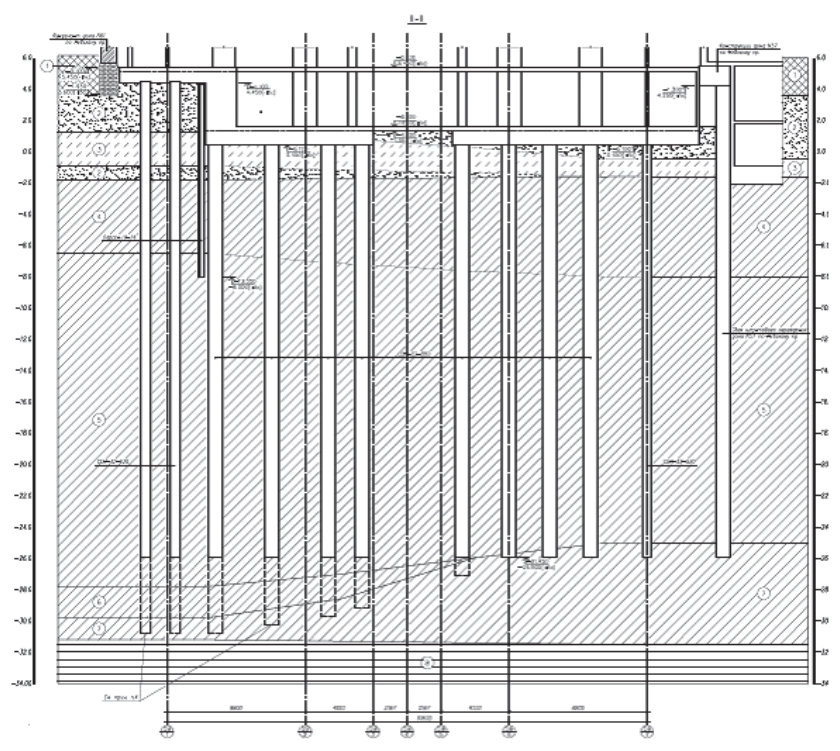

Figure 7. The cross section of the basement and piles with the difference depth according of the level bearing capacity soils. constructing the piles for the new Hotel building at 59 Nevsky Prospekt, the additional deformations of their foundations were less than $20 \mathrm{~mm}$ and no damages occurred in their superstructures.

As sheet piling for an excavation pit 4,5 to 6,2 m deep for an underground floor of a new Hotel Building at 55 Nevsky Prospekt, it was used the Larsen IV pile sheeting driven by a Muller non-resonant vibration generator in the area along Stremyannaya Street and the ALCELOR jacked pile sheeting driven by a press system of cassette type installed on a base of a Banut 655 pile-driving machine (Figure $8 \mathrm{a}$ and $\mathrm{b}$ ).

Back at the time when the non-standard additional settlement started developing, a decision was made to underpin their ground beds and, for one of the wings, to strengthen the superstructures with metal bands. The pile sheeting was jacked along Building No. 53, Nevsky Prospekt. At different depths along the line of the pile sheeting jacking, various inclusions were encountered in the form of timber sleepers, old rubble stone foundations and large boulders. To withdraw the inclusions, a trench was excavated down to a depth of $2,7 \mathrm{~m}$. This resulted in additional settlement of approximately $25 \mathrm{~mm}$ for the buildings at a distance of less than $2 \mathrm{~m}$ from the excavation pit. In the following pit excavation, these settlements increased and reached up to $60 \mathrm{~mm}$ for individual benchmarks. The geodetic monitoring of the facade verticality for the existing Hotel building showed its deviation up to 50 $\mathrm{mm}$ from the vertical line towards Nevsky Prospekt. In view of that, a prompt decision was made to underpin the foundation of that wall with drilled injected piles $14 \mathrm{~m}$ long and $150 \mathrm{~mm}$ in diameter. The action taken made it possible to complete the construction of the substructure and to start constructing the superstructures [3].

Further geodetic monitoring of the settlements for the new buildings and the neighboring buildings identified no hazardous tendencies. By the end of the construction, the settlements of the new buildings did not exceed $30 \mathrm{~mm}$, and the settlements of the neighboring buildings stabilized.

At the end of May 2009, the new Hotel buildings were successfully commissioned (Figure 9).

\section{CONCLUSION}

The experience of this construction showed how important is to comply with the requirements of 
a)

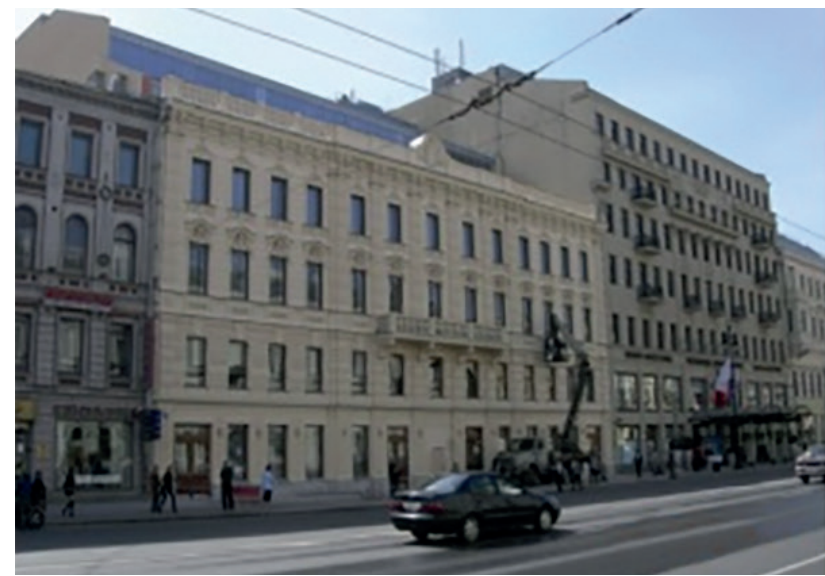

b)

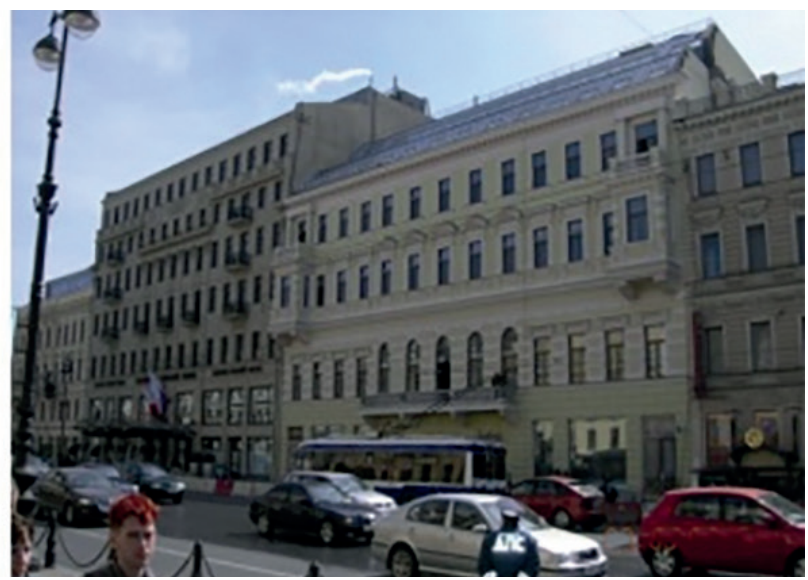

Figure 9. New buildings of Corinthia Nevsky Palace Hotel: $a$-Building No. 59; b-Building No. 55

the construction operations method and to take into consideration the specific engineering and geological conditions of a given construction site. Our experience shows that even the use of the most state-of-the-art foreign technologies without adapting them to the application in soft water-saturated silty-clayed soils of Saint Petersburg may result in dramatic consequences. Thus, the use of secant augered cast-in-place piles for the pit sheeting without a special-purpose cutting working head that allows minimizing the dynamic action on soft soils becomes unacceptable and hazardous when constructing in the compact building systems. Later on, domestic geotechnical companies began using, in construction of pit sheeting of augered cast-in-place piles, a system of adjoining piles injecting cement mortar between them.

\section{REFERENCES}

1. Mangushev R., Oshurkov N., Igoshin A. Use of mobile installation for purposes of reconstruction and construction in the constrained condition of Saint-Petersburg. The collection of reports of Int. scientific-practical conf. «Reconstruction of SaintPetersburg-2005», Part I, Saint-Petersburg,2005 - p.p. 214-218/

2. Mangushev R., Osokin A. Geotechnics of SaintPetersburg. Publ.HouseASV, Moscow, 2010.-260p.

3. Mangushev R., Yershov A., Osokin A. Modern Pile Construction Technology. 2nd Edition, revised and updated, Moscow, Publishing House of Association of Construction Higher Education Institutions, 2010. $-240 \mathrm{p}$.
4. Mangushev R., Usmanov R, Osokin A. Geotechnical problems in designing buildings and structures in soft water-saturated soil conditions (by example of northern and southern regions) Monograph. Academic Publ. House LAMBERT, 2015. - 457 p.

5. Dalmatov B.I., etc. The Footing and Foundations. Textbook for High School, Publ.house ASV, Moscow, 2002. - 387 p.

6. Hosseinzaden S., Jaap F. Joosse. Design optimization of retaining walls in narrow trenches using both analytical and numerical methods. Computers and Geotechnics. Vol.69, 2013 p. 338-351

7. Ulitsky V.M., Shashkin A.G., Shashkin K.G. Geotechnical maintenance of development of the cities. Saint-Petersburg., Stroyizdat SeveroZapad, 2010 - 551p.

8. Ilyichev V.A., Mangushev R.A., Nikiforova N.S. Experience in the development of the underground space of Russian megacities. Scientific Journal «Osnovaniya, Fundamenty I mekhanika gruntov.» №2 Moscow, 2012 - p.17-20

9. Ilyichev V.A. Konovalov P.A., Nikiforova N.S. Geotechnical monitoring of urban building reconstruction during the underground construction.// Proc. XVth ISMGE. The 1st Int.Conf.of the Third Millenium. Istanbul, 2001. Vol 2. pp. 1347-1348

10. Efimov V., Osokin A., Kondratieva L. Development of engineering methods for calculating combined pile-raft foundation (CPRF). Contemporary problems of architecture and construction. Proceed. Of9-th Int. Conf. Batumi, Georgia, 2017-p.441-445

11. Konovalov P.A. The bases and foundations of reconstructed buildings. 4th edition - Moscow, VNIINTPI, $2000-317$ p. 
12. Kuntsche K. Deep excavations and slopes in urban areas. // Proc. of the 14-th European Conf. on ISMGE. Madrid, 2007.Vol.1, pp. 63-73

13. EN 1997-1: 2004 (E). Eurocode 7: Geotechnical Engineering.

14. Ulitsky V., Shashkin A. Underground construction in cities on soft soil. // Proc.of the Int. Geotechnical Conf. Development of Urban Areas and Geotechnical Engineering, SaintPetersburg. 2008 - pp. 3-12.

\section{СПИСОК ЛИТЕРАТУРЫ}

1. Мангушев Р., Ошурков Н., Игошин А. Использование мобильной установки для целей реконструкции и строительства в стесненных условиях Санкт-Петербурга// Сб.Тр. Междунар. науч.- практич.конф. «Реконструкция СанктПетербург-2005», Ч.І, СПб, 2005 - с. 214-218

2. Мангушев Р.А., Осокин А.И. Геотехника СанктПетербурга. - М.: Изд-во АСВ, 2010 - 260 с.

3. Мангушев Р.А., Ершов А.В., Осокин А.И. Современные свайные технологии. - М.: Издво ACB , 2010 - 240c.

4. Мангушев Р.А., Усманов Р.А., Осокин А.И. Геотехнические проблемы проектирования зданий и сооружений в сложных грунтовых условиях на слабых водонасыщенных грунтах. - Изд-во LAMBERT, 2015 - 457 с.

5. Далматов Б.И. Основания и фундаменты. Учебн.для ВУЗов, М.: Изд-во АСВ, 2002 -387 с.

6. Hosseinzaden S., Jaap F. Joosse, Design optimization of retaining walls in narrow trenches using both analytical and numerical methods. Computers and Geotechnics. Vol.69, 2013 p. 338-351.

7. Улицкий В.М., Шашкин А.Г., Шашкин К.Г. Геотехнические проблемы развития городов. - СПб.: Из-во «Север-Запад». 2010 - 551 с.

8. Ильичев В.А., Мангушев Р.А., Никифорова Н.С. Опыт развития подземного пространства в мегаполисах России. // Науч. Журнал «Основания, фундаменты и механика грунтов», №2, M. 2012 - c.17-20.

9. Ilyichev V.A. Konovalov P.A., Nikiforova N.S. Geotechnical monitoring of urban building reconstruction during the underground construction. // Proc. XVth ISMGE. The 1st Int.Conf.of the Third Millenium. Istanbul, 2001. Vol 2. pp. 1347-1348.

10. Efimov V., Osokin A., Kondratieva L. Development of engineering methods for calculating combined pile-raft foundation (CPRF). Contemporary problems of architecture and construction. Proceed. Of 9-th Int. Conf. Batumi, Georgia, 2017 - p. 441-445.

11. Коновалов П.А. Основания и фундаменты реконструируемых зданий. 4изд., - М.: ВНИИНТПИ. 2000. - 317c.

12. Kuntsche K. Deep excavations and slopes in urban areas. // Proc. of the 14-th European Conf. on ISMGE. Madrid, 2007.Vol.1, pp. 63-73.

13. EN 1997-1: 2004 (E). Eurocode 7: Geotechnical Engineering.

14. Улицкий В.М., Шашкин А.Г. Подземное строительство в городах на слабых грунтах.// Сб. Тр. междунар. геотехнич. конф. « Развитие городов и геотехническое строительство». СПб.2008 - с. 3-12.

R.A.Mangushev - Head of geotechnical department Saint-Petersburg state university of architecture and civil engineering, Honorary Figure of Russian Higher Education, Laureate of Russian Government prize, Dr.Sc., professor; address: department of geotechnics, SPbGASU, h.5, Egorova str., Saint-Petersburg, Russia, 190103. e-mail: ramangushev@yandex.ru

Р.А. Мангушев, заведующий кафедрой геотехники Санкт-Петербургского государственного архитектурно-строительного университета, член-корреспондент РААСН, Заслуженный работник высшего образования РФ, лауреат Премии Правительства РФ, доктор технических наук, профессор; 190103, Россия, Санкт-Петербург, ул.Егорова, д. 5, кафедра геотехники СПбГАСУ ; тел. +7 (812) 316-03-41. e-mail: ramangushev@yandex.ru

A.I.Osokin - reader of geotechnical department Saint-Petersburg state university of architecture and civil engineering, Ph.D, address: department of geotechnics, SPbGASU, h.5, Egorova str., Saint-Petersburg, Russia, 190103. e-mail: geostroy-osokin@mail.ru

А.И. Осокин, доцент кафедры геотехники Санкт-Петербургского государственного архитектурно-строительного университета, кандидат технических наук; 190103, Россия, Санкт-Петербург, ул. Егорова, д. 5, кафедра геотехники СПбГАСУ ; тел. +7 (812) 316-03-41. e-mail: geostroy-osokin@mail.ru 